\title{
ÖĞRETMEN ADAYLARININ AÇIK UÇLU VE ÇOKTAN SEÇMELİ MADDELERE YÖNELIK ALGILARININ METAFORLAR ARACILIĞIYLA BELIIRLENMESI
}

\author{
DETERMINING THE PERCEPTIONS OF PROSPECTIVE TEACHERS IN \\ RELATION TO OPEN-ENDED AND MULTIPLE CHOICE ITEMS \\ THROUGH METAPHORS
}

\author{
Emine Burcu TUNÇ ${ }^{1}$ - Müge ULUMAN²
}

\section{$\ddot{O} z$}

Bu araştırmanın amacı, öğretmen adaylarının açık uçlu ve çoktan seçmeli maddelere yönelik algılarının metaforlar aracılığıyla belirlenmesidir. Araştırma kapsamında olgu bilim yaklaşımı kullanılmıştır. Araştırmanın çalışma grubunu, 2016-2017 öğretim yılı güz dönemi, Marmara Üniversitesi Atatürk Eğitim Fakültesinde pedagojik formasyon kapsamında eğitim gören 183 öğretmen adayı oluşturmaktadır. Öğretmen adaylarının, açık uçlu maddelere ilişkin sahip oldukları algılarını ortaya çıkarmak için, "Açık uçlu maddeler... gibidir; çünkü ..." cümlesini ve çoktan seçmeli maddelere ilişkin sahip oldukları algılarını ortaya çıkarmak için ise "Çoktan seçmeli maddeler... gibidir; çünkü ..." cümlesini tamamlanmaları istenmiştir. Elde edilen verilerin değerlendirilmesinde içerik analizi kullanılmıştır. Araştırmanın bulgularına göre öğretmen adayları açık uçlu maddelere ilişskin olarak toplam 78 adet ve çoktan seçmeli maddelere ilişkin olarak da 65 adet farklı ve geçerli metafor üretmişlerdir. Açık uçlu maddelere ilişkin "kapsamlı ve sonsuz oluşu", "sınanana kendini ifade etme olanağı sunmass", "öznel ve yoruma açı oluşu", "zor ve korkutucu olması", "zihinsel becerileri geliştirmesi" olmak üzere toplam beş tema belirlenmiş̧ir. Çoktan seçmeli maddelere ilişkin olarak ise "şans faktörünün olması", "seçenekler arasından yanıt verilmesi", "sınırlarının olması", "tek bir doğru yanıtın olması", "avantajlarının olması" ve "ya hep ya hiç olma durumu" olmak üzere altı tema belirlenmiştir. Araştırmadan elde edilen metaforlar ve temalar incelendiğinde, açık uçlu maddelerin olumlu özelliklerinin daha fazla vurgulandığı ve açığa çıktığı ortaya konulmuştur.

Anahtar Kelimeler: metafor, açık uçlu madde, çoktan seçmeli madde, olgu bilim, içerik analizi.

\begin{abstract}
The aim of this research is to determine the perceptions of prospective teachers for open-ended and multiple-choice items through metaphors. Within the scope of the research phenomenological approach was used. The study group constitutes 183 teacher candidates trained within the pedagogical formation of Marmara University Atatürk Education Faculty during the fall semester of 2016-2017 academic year. In order to reveal the prospective teachers' perceptions of open-ended items, they are asked to complete the sentence as "Open-ended items are like...; Because ..." and in order to reveal their perceptions of multiple choice items, they are asked to complete sentences as "Multiple choice items are like ...; Because ...". Content analysis was used to evaluate the obtained data. According to the findings of the research, the prospective teachers produced 78 different and valid metaphors regarding open ended items and 65 different and valid metaphors regarding multiple choice items. A total of five themes have been identified for open ended items, including "comprehensive and endless formation", "giving the chance to the test taker to express himself/herself", "being subjective and open to interpretation", "being difficult and frightening", and "developing mental skills". With regard to multiple choice items, six themes have been identified, including "chance factor", "giving an answer from options", "having boundaries", "having one correct answer", "having advantages" and "being all or nothing". When the metaphors and the themes obtained from the research were examined, it was revealed that the positive features of the open-ended items were mentioned and emphasized more.
\end{abstract}

Keywords: metaphor, open-ended item, multiple choice item, phenomenological approach, content analysis.

\footnotetext{
${ }^{1}$ Öğr. Gör. Dr., Marmara Üniversitesi, Atatürk Eğitim Fakültesi, Eğitim Bilimleri Bölümü, Eğitimde Ölçme ve Değerlendirme ABD, mugeulumann@gmail.com

2 Öğr. Gör. Dr., Marmara Üniversitesi, Atatürk Eğitim Fakültesi, Eğitim Bilimleri Bölümü, Eğitimde Ölçme ve Değerlendirme ABD, burcupehlivantunc@gmail.com
} 


\section{GİRIȘ}

Eğitimde öğrencilerin başarı düzeylerinin ölçülüp değerlendirilmesinde çeşitli ölçme ve değerlendirme araçları kullanılmaktadır. Öğrencilerin hangi davranışları değerlendirilecekse, o davranışlara uygun ölçme aracının seçilmesi son derece önemlidir. Bu araçlardan biri sıkça kullanılan çoktan seçmeli testlerdir. Çoktan seçmeli testlerin öğretmen ve öğrenciler tarafından diğer ölçme araçlarına göre daha fazla tercih edildiği yaygın bir düşüncedir. Bunun en önemli nedeni Türkiye'de yapılan Öğrenci Seçme ve Yerleştirme Sınavlarının (ÖSYS) varlığıdır. Çoktan seçmeli maddeler, problemin yer aldığı madde kökü ile probleme ilişkin doğru ve yanlış yanıtları içeren seçeneklerden oluşmaktadır. Kurz (1999), çoktan seçmeli testlerin; geniş bir içerik örneklemesi, yüksek güvenirlik, kolay uygulanabilirlik, farklı içerikli sınavlarda kullanışl1lık ve nesnel puanlanabilme özelliklerine sahip olmasından dolayı, hem büyük sınav düzenlemelerinde hem de sınıf içi sınavlarda öğretmenler tarafından kullanımının uygun görüldüğünü belirtmektedir. Haladyna (1997) çoktan seçmeli maddelerin sınırlılıklarını ise öğrenme üzerindeki etkisi, belli amaçlara (yaratıcı düşünme, yazma vb.) hizmet edecek nitelikte madde yazılamaması ve yazma becerisinden yoksunluk biçiminde ifade etmiştir. Doğru yanıtın bulunması noktasında ölçülen bilgiye sahip olunmaksızın test becerisiyle hareket etmeye yönlendirmesi ve şans başarısı da çoktan seçmeli maddelerin sınırlılıkları arasında gösterilmiştir. Birçok geniş ölçekli ulusal ve uluslararası değerlendirme çalışmaları (Ulusal Eğitimsel İlerlemeyi Değerlendirme, Uluslararası Öğrenci Değerlendirme Programı, Uluslararası Matematik ve Fen Eğilimleri Çalışması) hem çoktan seçmeli hem de açı uçlu maddeleri içermektedir (DeCarlo, Kim ve Johnson, 2011; Mariano, 2002). ÖSYM de 2017 Lisans Yerleştirme Sınavlarında (2017-LYS) kısa cevaplı maddelerin yer alacağını açıklamıştır.

Çoktan seçmeli maddelerin aksine açık uçlu maddeler; seçenekler arasından doğru yanıtı seçmek yerine sınananların kendi yanıtlarını yapılandırmalarını gerektirir (Kastner ve Stangla, 2011; Rodriquez, 2002; Roid ve Haladyna, 1982). Açık uçlu maddelerin kullanımıyla, sınanan bireydeki bilgiye ilişkin daha derin ölçmeler yapılabilir ve çoktan seçmeli maddelerde sıklıkla karşılaşılan sınav deneyimi probleminden kaçınılabilir (Pollack, Rock ve Jenkins, 1992; Rodriquez, 2002). Diğer madde türleriyle birlikte öne çıkan bu iki madde türünü de kullanacak olan öğretmen ve öğretmen adaylarının maddelere ait özellikleri, avantaj ve dezavantajları bilmeleri, bu bilgileri yorumlayabilmeleri ve düzenleyebilmeleri gerekir. Bu nedenle özellikle mesleğe yeni başlayacak olan öğretmen adaylarının algılarının belirlenmesi ve bu doğrultuda eksikliklerin giderilmesine yönelik önlemlerin alınması önemli görülmektedir.

Algıların tespit edilmesinde birçok farklı yöntem (anketler, ölçekler, görüşme vb.) kullanılmakla birlikte, bir bireyin yüksek düzeyde soyut, karmaşık veya kuramsal bir olguyu anlamada ve açıklamada işe koşabileceği güçlü bir zihinsel araç olan metaforlar da kullanılabilmektedir (Saban, 2008). Meta (öte) ve pherein (taşımak) kelimelerinden türetilmiş olan metafor (Demir, 2005); Türkçe'de mecaz, benzetme anlamına gelmektedir. Metafora ilişkin yapılmış birçok farklı tanım bulunmaktadır; yaratıcılığın dile aktarılmış biçimi (Kortens, 1988), iki durum ya da kavramı birbirine bağlayan sembolik bir araç (Palmquist, 2001), bir tür şeyi başka bir tür şeye göre anlamak ve deneyimlemektir (Lakoff ve Johnson, 2005). Metaforlar, bireylerin kendi dünyalarını anlamalarına ve yapılandırmalarına yönelik güçlü bir zihinsel modelleme mekanizmasıdır (Arslan ve Bayrakçı, 2006). Bir algı aracı olan metaforlar insanın doğayı ve çevresini anlamasına, nesnel gerçeklikten belirli yorumlar yoluyla anlamlar çıkarmasına, yaşantı ve deneyime anlam kazandırmasına olanak sağlayan araçlar olarak "bilmeye" de imkân sunduğu belirtilmektedir (Yıldırım ve Şimşek, 2008).

Öğretmen eğitiminde metaforlar, eğitim ve öğretim uygulamalarını yönlendirmede, öğretmen adaylarının eğitim anlayışındaki yerini belirlemede, eğitimde planlama, eğitim 
programı geliştirme, öğrenmeyi teşvik etme ve yaratıcı düşünceyi geliştirmede bir araç olarak kullanılabilir (Aydın ve Pehlivan, 2010). Eğitim alanı kapsamında yapılmış olan metaforik çalışmalar incelendiğinde genel olarak öğretmen (Bozdemir ve Uluman, 2012; Ekiz ve Koçyiğit, 2013; Goldstein, 2005; Pektaş ve Kıldan, 2009; Saban, 2004), öğrenci (Saban, 2009; Stofflett, 1996), okul (Aydoğdu, 2008; Mahlios ve Maxon, 1998; Nalçacı ve Bektaş, 2012; Özdemir, 2012), yönetici (Yalçın ve Erginer, 2012), müfettiş (Döş, 2010; Töremen ve Döş, 2009), değerlendirme (Tatar ve Murat, 2011), öğrenme ve öğretim (Gross ve Hogler, 2005; Johnson, 2005; Saban, Kocbeker ve Saban, 2007), öğretim (Bullough, 1991; Bullough ve Stokes, 1994) kavramları üzerinde çalışılmış olduğu belirlenmiştir.

Ölçme ve değerlendirme kapsamı ile ilgili olarak yapılmış metafor çalışmaları incelendiğinde belirli bir konu alanından ziyade, genel anlamda metaforların belirlenmesine yönelik oldukları (Gök, Erdoğan, Özen-Altınkaynak ve Erdoğan, 2012; Günal, 2014; Güvendir ve Özkan, 2016; Tatar ve Murat, 2011) görülmektedir. Madde türleri ya da ölçme ve değerlendirme araçlarına ilişkin gerçekleştirilmiş bir metaforik çalışmaya rastlanmamıştır. Dolayısıyla bu araştırma ilgili konuda yapılan çalışmaların bulunmayışı açısından gerekli ve önemli görülmekte ve alan yazına katkı sağlayacağı düşünülmektedir.

Araştırmanın amacı, öğretmen adaylarının çoktan seçmeli ve açık uçlu maddelere ilişkin algılarını metaforlar aracılığıyla belirlemektir. Bu amaç çerçevesinde, aşağıdaki sorulara yanıt aranmıştır:

1. Öğretmen adayları, açık uçlu maddelere ilişkin algılarını hangi metaforlar aracılığıyla açıklamaktadır?

2. Öğretmen adayları açık uçlu maddelere ilişkin belirledikleri metaforların nedenlerini nasıl açıklamaktadır?

3. Öğretmen adayları, çoktan seçmeli maddelere ilişkin algılarını hangi metaforlar aracılığıyla açıklamaktadır?

4. Öğretmen adayları çoktan seçmeli maddelere ilişkin belirledikleri metaforların nedenlerini nasıl açıklamaktadır?

\section{YÖNTEM}

\subsection{Araştırmanın Modeli}

Araştırma kapsamında olgu bilim (fenomenoloji) yaklaşımı kullanılmıştır. Olgu bilim yaklaşımı bireysel evrenin araştırılmasıdır, yani temelini bireysel tecrübeler oluşturmaktadır. $\mathrm{Bu}$ yaklaşımda araştırmacı katılımcının öznel tecrübeleri ile ilgilenmekte, bireyin algılamaları ve olaylara yönelik yükledikleri anlamları incelemektedir (Baş ve diğ., 2008). Olgu bilim yaklaşımına göre tek bir gerçeklik yoktur. Gerçeklik kişisel algılamalara dayanır ve zamanla değişebilir. Ne bildiğimiz, içinde bulunduğumuz duruma, çevre ve şartlara göre değişiklik gösterir (Giorgi ve Giorgi, 2003). Olgu bilim yaklaşımında olgulardaki gerçekliğin tanımlanması amaçlanmaktadır. $\mathrm{Bu}$ bağlamda genelleştirmelerin yapılması amaçlanmamaktadır. Tümevarımsal tanımlayıcı bir araştırma deseni olan olgu bilimde amaç, tüm olgunun göründüğü gibi tanımlanmasıdır. Bu araştırmada da ele alınan olgu öğretmen adaylarının "çoktan seçmeli maddeler, açık uçlu maddeler" kavramlarına ilişkin algılarıdır.

\section{2. Çalışma Grubu}

Araştırmanın çalışma grubunu, 2016-2017 öğretim yılı güz dönemi, Marmara Üniversitesi Atatürk Eğitim Fakültesinde pedagojik formasyon kapsamında eğitim almış olan öğretmen adayları oluşturmaktadır. Çalışmaya katılmış olan 183 öğretmen adayından \%20.77'si (38) İlahiyat Fakültesi, \%16.94'ü (31) Sağlık Bilimleri Fakültesi, \%16.39’u (30) Spor Bilimleri Fakültesi, \%15.85'i (29) İnsan ve Toplum Bilimleri Fakültesi, \%15.30’u (28) 
İletişim Fakültesi ve \%14.75'i (27) Teknoloji Fakültesi mezunu olan öğretmen adaylarıdır. Farklı fakültelerden mezun olmuş olan öğretmen adaylarının çalışmaya dahil olmuş olması, farklı eğitim ve ölçme-değerlendirme süreçlerinden geçmiş olan öğretmen adaylarından farklı metaforlar alınmış olmasına yardımcı olmuştur.

\subsection{Verilerin Toplanması}

Veri toplama aracının hazırlanması amacıyla, literatürde yer alan metaforik çalışmalar incelenmiştir (Arıkan ve Ünal, 2014; Duman ve Çetin, 2014; Gök vd., 2012; Günal, 2014; Güvendir ve Özkan, 2016; Taşgın ve Köse, 2015). İnceleme sonucunda; genellikle katılımcıların '...... gibidir. Çünkü...' sorusuna yanıt vermelerinin istendiği görülmüştür. Bu doğrultuda katılımcılara

- Çoktan seçmeli maddeler... gibidir. Çünkü...

- Açık uçlu maddeler ... gibidir. Çünkü...

soruları yazılı olarak yöneltilmiş ve $15-20 \mathrm{dk}$ vererek yanıtlamaları istenmiştir. Yanıtlamaları tamamlandığında yanıtları içeren veriler toplanmıştır.

\subsection{Verilerin Analizi}

Elde edilen veriler içerik analizinden faydalanılarak çözümlenmiştir. İçerik analizi, sözel ve yazılı verilerin belirli bir problem veya amaç bakımından sınıflandırılması, özetlenmesi, belirli bir değişken veya kavramların ölçülmesi ve bunlardan belirli bir anlam çıkarılması için taranarak kategorilere ayrılmasıdır (Tavşancıl ve Aslan, 2001). Başka bir anlatımla psikoloji, sosyoloji, tarih, edebiyat, gazetecilik gibi değişik alanlarda farklı amaçlarla kullanılabilen, temelde davranışları doğrudan gözlemek yerine, bireylerin sembolik davranışlarını ya da iletişim materyallerini çözümleyen tekniktir. İçerik analizinde gerçekleştirilen temel işlem birbirine benzeyen veriyi belirli kavramlar ve temalar çerçevesinde bir araya getirmek ve bunları okuyucunun anlayabileceği bir biçimde düzenleyerek yorumlamaktır (Yıldırım ve Şimşek, 2008).

Öğretmen adaylarının geliştirdikleri metaforların analiz edilmesi ve yorumlanması süreci beş adımda analiz edilmiştir. Bu aşamalar; (1) adlandırma, (2) tasnif etme, (3) tema geliştirme, (4) geçerlik ve güvenirlik çalışmasıdır (Saban, 2008; 2009).

1. Adlandırma Aşaması: Bu aşamada öğretmen adayları tarafından üretilen metaforlar nedenleriyle birlikte not edilmiş ve alfabetik sıraya konularak listelenmiştir. Bu süreçte net bir metafor imgesi içermeyen, metafor imgesi ya da nedeni boş bırakılan ya da birden fazla metafor imgesi sunun katılımcıların kağıdı analiz dışında tutulmuştur. Bu doğrultuda elde edilmiş olan 183 metafordan açık uçlu maddelere ilişkin 162, çoktan seçmeli maddelere ilişkin 159 metaforla çalışmaya devam edilmiştir.

2. Tasnif Etme Aşaması: İkinci aşamada ise öğretmen adaylarının metaforlarına ilişkin gerekçeleri gözden geçirilmiş ve bazı katılımcıların belirttiği metafora ilişkin hiçbir gerekçe sunmadığı, bazılarının sunduğu metafora dönük gerekçesinin ilişkili olmadığ belirlenmiş ve bu nedenlerle, açik uçlu maddelere ilişkin 132, çoktan seçmeli maddelere ilişkin 112 metafor ortaya çıkmıştır. Daha sonra metaforlar arasındaki benzerlikler göz önünde bulundurularak metaforların nedenleri sınıflandırılmıştır. Sonuç olarak, açık uçlu maddelere ilişkin 78, çoktan seçmeli maddelere ilişkin 65 adet farklı ve geçerli metaforla çalışmaya devam edilmiştir.

3. Tema Geliştirme Aşaması: Bu aşamada metaforlar ortak özellikleri bakımından incelenmiş ve bu inceleme sonucunda üretilen metaforları açıklayan temalara ulaşılmıştır. Açık uçlu maddelere ilişkin oluşturulmuş temalar; kapsamlı ve sonsuz oluşu, sinanana kendini ifade etme olană̆ı sunması, öznel ve yoruma açık oluşu, zor ve korkutucu olması, zihinsel becerileri 
geliştirmesi olarak belirlenmiştir. Çoktan seçmeli maddelere ilişkin oluşturulmuş temalar ise şans faktörünün olması, tek bir doğru yanıtın olması, seçenekler arasından yanıt verilmesi, sınırlarının olması, ya hep ya hiç olma durumu, avantajlarının olması olarak belirlenmiştir.

4. Geçerlik ve Güvenirlik Çalışması: Nitel verilerle yapılan araştırmalarda geçerliğin ve güvenirliğin sağlanması, verilerin toplanmasından sonuçların rapor edilmesi sürecine kadar aşılan her bir aşamanın detaylı olarak sunulmasıyla mümkündür (Yıldırım ve Şimşek, 2008). $\mathrm{Bu}$ nedenle tüm aşamalar ayrıntılarıyla birlikte raporlanmış ve her bir temadaki metaforlara ilişkin katılımcıların doğrudan ifadeleri sunulmuştur. Bunun yanı sıra, temaların ilgili oldukları metaforları temsil edip etmediklerini belirlemek için uzman görüşüne başvurulmuştur. $\mathrm{Bu}$ doğrultuda eğitim fakültesinde görev yapan bir ölçme ve değerlendirme uzmanına kategoriler ve metaforlar verilmiş ve her bir metaforu temsil ettiği ilgili kategoriye ataması istenmiştir. Daha sonra araştırmacıların gerçekleştirdiği eşleştirmeler ile alan uzmanının gerçekleştirdiği eşleştirmeler karşılaştırılmış ve Miles ve Huberman'ın (1994) formülü (Güvenirlik = görüş birliği / görüş birliği + görüş ayrılığı X 100) kullanılarak güvenirliğin göstergesi olan uyum katsayısı hesaplanmıştır. Bu formül aracılığıyla çoktan seçmeli maddeler için 106/106+6 X 100 $=\% 95$ açı uçlu maddeler için ise 128/128+4 X $100=\% 97$ katsayıları elde edilmiştir. Eşik değer olarak kabul edilen $\% 90$ uyumun üzerinde elde edilen bu değerler araştırmanın güvenirliğine ilişkin kanıt olarak ele alınmıştır.

\section{BULGULAR VE YORUMLAR}

\subsection{Açık Uçlu Maddelere İlişkin Bulgular ve Yorumlar}

Öğretmen adaylarının açık uçlu maddelere ilişkin algılarına yönelik elde edilen geçerli metaforlara ait frekans ve yüzde değerleri Tablo 1'de verilmiştir.

Tablo 1. Öğretmen adaylarının açık uçlu maddelere ilişkin geliştirdikleri geçerli metaforlar, frekans ve yüzde değerleri

\begin{tabular}{lllllllll}
\hline Metafor & f & $\mathbf{\%}$ & Metafor & f & $\mathbf{\%}$ & Metafor & f & \% \\
\hline Deniz & 21 & 15.91 & Hassas terazi & 1 & 0.76 & Tarla & 1 & 0.76 \\
\hline Okyanus & 13 & 9.85 & Kuşlar & 1 & 0.76 & Uçurtma & 1 & 0.76 \\
\hline Ev yemeği & 4 & 3.03 & Yolculuk & 1 & 0.76 & Monolog & 1 & 0.76 \\
\hline Özgürlük & 4 & 3.03 & Beyin firtınası & 1 & 0.76 & Ağaç & 1 & 0.76 \\
\hline Sanat & 4 & 3.03 & Demokrasi & 1 & 0.76 & Balon & 1 & 0.76 \\
\hline Hayat & 4 & 3.03 & Cevher & 1 & 0.76 & Güvenilmez insan & 1 & 0.76 \\
\hline Yol & 3 & 2.27 & Çiçek & 1 & 0.76 & Kalp krizi & 1 & 0.76 \\
\hline Lastik & 2 & 1.52 & Doğa & 1 & 0.76 & Cankurtaran & 1 & 0.76 \\
\hline Sonsuzluk & 2 & 1.52 & Ayna & 1 & 0.76 & Tükenmez kalem & 1 & 0.76 \\
\hline Destan & 2 & 1.52 & Bulmaca & 1 & 0.76 & Ölüm & 1 & 0.76 \\
\hline Resim yapmak & 2 & 1.52 & Kare bulmaca & 1 & 0.76 & İp & 1 & 0.76 \\
\hline Tuval & 2 & 1.52 & Tünel & 1 & 0.76 & Dağın tepesi & 1 & 0.76 \\
\hline Gökyüzü & 2 & 1.52 & Araba kullanmak & 1 & 0.76 & Ufuk & 1 & 0.76 \\
\hline Resim kâğıdı & 2 & 1.52 & Demir & 1 & 0.76 & Karabasan & 1 & 0.76 \\
\hline Tablo & 2 & 1.52 & Kaplumbağa & 1 & 0.76 & Sanatçı & 1 & 0.76 \\
\hline Ev yapımı kek & 1 & 0.76 & Korku tüneli & 1 & 0.76 & Masa & 1 & 0.76 \\
\hline Bahçeli ev & 1 & 0.76 & Oyun hamuru & 1 & 0.76 & Şiir & 1 & 0.76 \\
\hline Roman & 1 & 0.76 & Nar & 1 & 0.76 & Satranç & 1 & 0.76 \\
\hline Röntgen cihazı & 1 & 0.76 & Dikiş & 1 & 0.76 & Arkadaş & 1 & 0.76 \\
\hline Dram filmi & 1 & 0.76 & Aşk & 1 & 0.76 & Güzellik & 1 & 0.76 \\
\hline Kara delik & 1 & 0.76 & Felsefe & 1 & 0.76 & Renk & 1 & 0.76 \\
\hline Biyografi & 1 & 0.76 & Açık büfe & 1 & 0.76 & Çantada keklik & 1 & 0.76 \\
\hline Sosyolog & 1 & 0.76 & Serbest piyasa & 1 & 0.76 & Uçurum & 1 & 0.76 \\
\hline Günlük & 1 & 0.76 & Boş bir ev & 1 & 0.76 & Deneme yazıları & 1 & 0.76 \\
\hline Bulutlar & 1 & 0.76 & Kitap & 1 & 0.76 & Nota & 1 & 0.76 \\
\hline Göl & 1 & 0.76 & Çiçek tarlası & 1 & 0.76 & Çanta & 1 & 0.76 \\
\hline
\end{tabular}


Tablo 1 incelendiğinde, öğretmen adaylarının açık uçlu maddelere ilişkin olarak toplam 132 adet geçerli metafor üretilmiş olmakla birlikte toplam 78 adet farklı metafor olduğu görülmektedir. En s1k tekrarlama sayısına sahip metaforlar; "Deniz (\%15.91), Okyanus (\%9.85), Ev yemeği (\%3.03), Özgürlük (\%3.03), Sanat (\%3.03), Hayat (\%3.03), Yol (\%2.27), Lastik (\%1.52), Sonsuzluk (\%1.52), Destan (\%1.52), Resim yapmak (\%1.52), Tuval (\%1.52), Gökyüzü (\%1.52), Resim kâğıdı (\%1.52), Tablo (\%1.52)" olmuştur. Bu metaforlar dışında kalan 63 (\%47.73) metafor ise bir öğretmen adayı tarafından ifade edilmiştir. Bu bağlamda öğretmen adayları tarafından açık uçlu maddelere ilişkin çok sayıda farklı metafor kullanıldığı ve bunların büyük çoğunluğunun pozitif anlamlara sahip olduğu ifade edilebilir.

Öğretmen adaylarının geliştirmiş oldukları metaforların nedenlerine ilişkin frekans ve yüzde değerleri ise Tablo 2'de verilmiştir.

Tablo 2. Öğretmen adaylarının açık uçlu maddelere ilişkin geliştirdikleri metaforların nedenleri, frekans ve yüzde değerleri

\begin{tabular}{lll}
\hline Nedenler & f & $\mathbf{\%}$ \\
\hline Özgürlük ve sınırsızlık & 35 & 26.52 \\
Yapılandırılabilir & 24 & 18.18 \\
Yoruma açık olması & 20 & 15.15 \\
Kendini rahat ifade etmeni sağlar & 11 & 8.33 \\
Geniş ve Kapsamlı & 10 & 7.58 \\
Korkutucu & 9 & 6.82 \\
Göreceli & 6 & 4.55 \\
Öğrencinin öğretmen tarafından anlaşılmasını kolaylaştırır & 5 & 3.79 \\
Güvenilir değil & 3 & 2.27 \\
Zaman alıcı ve uğraştırıcı & 3 & 2.27 \\
Zihin açıcı & 3 & 2.27 \\
Güvenilir & 2 & 1.56 \\
Zor & 1 & 0.76 \\
\hline
\end{tabular}

Tablo 2'de yer alan metaforların nedenleri incelendiğinde öğretmen adaylarının \%26.52'si açık uçlu maddelerin özgür ve sınırsız, \%18.18'i yapılandırılabilir ve $\% 15.15$ 'i ise yoruma açık olduğunu belirtmişlerdir. $\mathrm{Bu}$ nedenlerle ilintili olarak öğretmen adaylarının \%8.33'ü kendilerini rahat ifade etmelerini sağladığını, \%7.58'i ise geniş ve kapsamlı olduğunu ifade etmişlerdir.

Öğretmen adaylarının açık uçlu maddelere yönelik sahip oldukları metaforların temalara atanma işlemi, metaforlar ve nedenleri tekrar incelenerek gerçekleştirilmiştir. $\mathrm{Bu}$ bağlamda; kapsamlı ve sonsuz oluşu, sınanana kendini ifade etme olanağı sunması, öznel ve yoruma açık oluşu, zor ve korkutucu olması, zihinsel becerileri geliştirmesi olmak üzere toplam beş tema belirlenmiştir. Hangi metaforların hangi temalar altında toplandığı Tablo 3 'te yer almaktadir. 
Tablo 3. Öğretmen adaylarının geliştirdikleri metaforlar ve atandıkları temalar

\begin{tabular}{|c|c|c|c|}
\hline Tema & Metafor & $\mathbf{f}$ & $\begin{array}{l}\text { Metafor } \\
\text { Sayısı }\end{array}$ \\
\hline $\begin{array}{l}\text { Kapsamının geniş } \\
\text { Olmast }\end{array}$ & $\begin{array}{l}\text { Tükenmez kalem (1), Okyanus (12), Deniz (17), Tünel (1), } \\
\text { Uçurtma (1), Balon (1), Kuşlar (1), Özgürlük (3), Bahçeli } \\
\text { ev (1), Kara delik (1), Felsefe (1), Biyografi (1), Gökyüzü } \\
\text { (2), Serbest piyasa (1), Günlük (1), Kitap (1), Çanta (1), } \\
\text { Dağın Tepesi (1), }\end{array}$ & 48 & 18 \\
\hline $\begin{array}{l}\text { Sinanana kendini } \\
\text { ifade etme olanağı } \\
\text { sunmast }\end{array}$ & $\begin{array}{l}\text { Nar (1), Yol (3), Arkadaş (1), Sonsuzluk (2), Okyanus (1), } \\
\text { Çiçek (1), Tuval (2), Ayna (1), Kare Bulmaca (1), Araba } \\
\text { kullanmak (1), Monolog (1), Ev yemeği (4), Resim kâğıdı } \\
\text { (2), Tablo (1), Sanat (2), Hayat (1), Masa (1), Oyun } \\
\text { hamuru (1), Resim yapmak (2), Açık büfe (1), Sosyolog } \\
\text { (1), Boş bir ev (1), Röntgen cihazı (1), Özgürlük (1), } \\
\text { Deneme yazıları (1), Deniz (1), }\end{array}$ & 36 & 26 \\
\hline $\begin{array}{l}\text { Öznel ve yoruma } \\
\text { açık olmast }\end{array}$ & $\begin{array}{l}\text { Lastik (2), Çantada keklik (1), Yolculuk (1), Demokrasi } \\
\text { (1), Hayat (2), İp (1), Beyin firtınası (1), Ev yapımı kek (1), } \\
\text { Destan (1), Ağaç (1), Cankurtaran (1), Ufuk (1), Sanatç1 } \\
\text { (1), Şiir (1), Roman (1), Deniz (2), Aşk (1), Güzellik (1), } \\
\text { Renk (1), Sanat (2), Bulutlar (1), Tarla (1), Göl (1), Çiçek } \\
\text { Tarlası (1), Tablo (1), Doğa (1) }\end{array}$ & 30 & 26 \\
\hline $\begin{array}{l}\text { Zor ve korkutucu } \\
\text { olmasi }\end{array}$ & $\begin{array}{l}\text { Karabasan (1), Korku tüneli (1), Kalp krizi (1), Ölüm (1), } \\
\text { Dram filmi (1), Destan (1), Deniz (1), Dikiş (1), Uçurum } \\
\text { (1), Nota (1), Hayat (1), Kaplumbağa (1), Güvenilmez } \\
\text { insan (1), }\end{array}$ & 13 & 13 \\
\hline $\begin{array}{l}\text { Zihinsel becerileri } \\
\text { geliştirmesi }\end{array}$ & $\begin{array}{l}\text { Satranç (1), Cevher (1), Bulmaca (1), Demir (1), Hassas } \\
\text { Terazi (1) }\end{array}$ & 5 & 5 \\
\hline
\end{tabular}

Tablo 3'te beş farklı tema ve temalara atanmış metaforların yer aldığı görülmektedir. $\mathrm{Bu}$ temalar tek tek incelendiğinde, en fazla tekrar eden metafor sayısına (48) sahip temanın 'Kapsamının geniş olması' başlıklı tema olduğu ve bu tema altında 18 farklı metafor üretildiği görülmektedir. Öğretmen adaylarının metafor ve nedenlerini nasıl ifade ettiklerine ilişkin örnekler aşağıda sunulmuştur.

'Açık uçlu maddeler tükenmez kalem gibidir; çünkü içinde sonsuzluğu özgürlüğü ve özerkliği barındırır.'

'Açık uçlu maddeler deniz gibidir; çünkü kapsamları uçsuz bucaksızdır.'

'Açık uçlu maddeler okyanus gibidir; çünkü çok geniştir.'

Bu tema altındaki metaforlar açık uçlu maddelerin kapsamlarının ne denli geniş olduğu, yanıtlarken özgürlük hissini içerdiğini vurgulamaktadır. Araştırma kapsamında yer alan ikinci ve üçüncü tema farklı tekrar sayılarına sahip olmakla birlikte aynı sayıda metafora sahiptir. Bu temalardan ilki 'Sınanana kendini ifade etme olanağı sunması' temasıdır. Toplam farklı 26 metafor barındıran temanın metafor tekrar sayısı ise 36' dır. Bu temaya ilişkin örnekler şöyledir;

'Açık uçlu maddeler arkadaş gibidir; çünkü kendini rahat ifade edersin.'

'Açık uçlu maddeler ev yemeği gibidir; çünkü sonunda içinde ne olduğunu bilerek ben yapılandirırım, mutlu eder.'

'Açık uçlu maddeler yol gibidir; çünkü önün açıktır kendini istediğin gibi ifade edersin.'

Bu tema altında yer alan metaforlar, açık uçlu maddelerle sınananların kendilerini ifade edebilmeleri ve yanıtı kendilerinin yapılandırabilmeleri özelliklerine odaklanmıştır. 'Sınanana kendini ifade etme olanağı sunması' temasıyla aynı sayıda farklı metafora (26) sahip olan diğer bir tema ise 'Öznel ve yoruma açık olması' temasıdır. Bu temanın tekrar eden metafor sayısı 
30'dur. Bu temada bulunan metaforların ortak özellikleri kişiden kişiye göre değișen yanıtlara sahip oluşu ve istendiği biçimde yorumlanma olanağı sunmasıdır. Öğretmen adaylarının metafor ve nedenlerini nasıl ifade ettiklerine ilişkin örnekler ise aşağıda yer almaktadır.

'Açık uçlu maddeler biyografi gibidir; çünkü öznel görüşlerini dile getirirsin.'

'Açık uçlu maddeler şiir gibidir; çünkü yoruma açıktır.'

'Açık uçlu maddeler çantada keklik gibidir; çünkü konu hakkında bilgin olmasa dahi yorumlamayla yolunu bulurum.'

Diğer bir tema ise 'Zor ve korkutucu olması' temasıdır. Bu tema altında 13 farklı metafor ve 13 tekrar sayısı bulunmaktadır. Metaforlar genellikle açık uçlu maddelerin zor olduğu, kayg1 ya da korku oluşturduğu güven vermediği özelliklerini kapsamaktadır. Metaforlar ve nedenlerine ilişkin örnekler aşağıda yer almaktadır.

'Açık uçlu maddeler destan gibidir; çünkü yazılması zordur.'

'Açık uçlu maddeler korku tüneli gibidir; çünkü nereden ne çıkacă̆ı belli olmaz.'

'Açık uçlu maddeler karabasan gibidir; çünkü içinden nasıl çıkarız bilmiyoruz.'

Son tema ise beş tekrar sayısı ve beş farklı metafora sahip olan 'Zihinsel becerileri geliştirmesi' temasıdır. Bu temadaki metaforlar daha çok açık uçlu maddelere maruz kalındığında zihinsel becerilerin geliştiğine vurgu yapar niteliktedir. Tema altında yer alan metafor ve nedenlerine aşağıda yer verilmiştir.

'Açık uçlu maddeler satranç gibidir; çünkü yazdıkça zihnin gelişir.'

'Açık uçlu maddeler cevher gibidir; çünkü zihnimizin derinliklerinde gizlenmiş bilgileri çıkarır.'

'Açık uçlu maddeler bulmaca gibidir; çünkü zihni daha çok çalıştırır.'

\section{2. Çoktan Seçmeli Maddelere İlişkin Bulgular ve Yorumlar}

Öğretmen adaylarının çoktan seçmeli maddelere ilişkin algılarına yönelik elde edilen geçerli metaforlara ait frekans ve yüzde değerleri Tablo 4 'te verilmiştir.

Tablo 4. Öğretmen adaylarının çoktan seçmeli maddelere dersine ilişkin geliştirdikleri geçerli metaforlar, frekans ve yüzde değerleri

\begin{tabular}{lllllllll}
\hline Metafor & $\mathbf{f}$ & $\mathbf{\%}$ & Metafor & $\mathbf{f}$ & $\mathbf{\%}$ & Metafor & $\mathbf{f}$ & $\mathbf{\%}$ \\
\hline Şans Oyunu & 13 & 11.61 & Demir & 1 & 0.89 & Armut & 1 & 0.89 \\
\hline Piyango & 8 & 7.14 & Nokta Atıș1 & 1 & 0.89 & Resmi Kurum & 1 & 0.89 \\
\hline Havuz & 5 & 4.46 & Renk & 1 & 0.89 & Çelik Kasa & 1 & 0.89 \\
\hline Kurtarıc1 & 5 & 4.46 & Navigasyon & 1 & 0.89 & İlaç & 1 & 0.89 \\
\hline Labirent & 4 & 3.57 & Harita & 1 & 0.89 & Sürpriz Hediye & 1 & 0.89 \\
\hline Dost & 4 & 3.57 & Puzzle & 1 & 0.89 & Banka & 1 & 0.89 \\
\hline Hazır Gıda/Yemek & 3 & 2.68 & Tek Yön & 1 & 0.89 & Ok ve Yay & 1 & 0.89 \\
\hline Bilim & 3 & 2.68 & Kelepçe & 1 & 0.89 & Hafiza Oyunu & 1 & 0.89 \\
\hline Açık Büfe & 2 & 1.79 & Leblebi & 1 & 0.89 & Fal & 1 & 0.89 \\
\hline Rus Ruleti & 2 & 1.79 & Yapboz & 1 & 0.89 & Kavşak & 1 & 0.89 \\
\hline Kapalı Kutu & 2 & 1.79 & Şeker & 1 & 0.89 & Matematik & 1 & 0.89 \\
\hline Televizyon & 2 & 1.79 & Ameliyat & 1 & 0.89 & Gölet & 1 & 0.89 \\
\hline Anahtar & 2 & 1.79 & Batak Oyunu & 1 & 0.89 & Şimşek & 1 & 0.89 \\
\hline Dart Tahtas1 & 2 & 1.79 & Menü & 1 & 0.89 & AVM & 1 & 0.89 \\
\hline Kumar & 2 & 1.79 & Çikolata & 1 & 0.89 & Bomba & 1 & 0.89 \\
\hline Hayat & 2 & 1.79 & Dört Odalı Ev & 1 & 0.89 & Bowling & 1 & 0.89 \\
\hline Kuruyemiş & 2 & 1.79 & Bahçe & 1 & 0.89 & Kader & 1 & 0.89 \\
\hline Duvar & 2 & 1.79 & Sayı & 1 & 0.89 & Oy Pusulas1 & 1 & 0.89 \\
\hline Çerçeve & 1 & 0.89 & Uçak & 1 & 0.89 & Çember & 1 & 0.89 \\
\hline
\end{tabular}




\begin{tabular}{lllllllll}
\hline Metro & 1 & 0.89 & Güvenilir İnsan & 1 & 0.89 & Metrobüs & 1 & 0.89 \\
\hline Ar1 & 1 & 0.89 & Bilmece & 1 & 0.89 & Lego & 1 & 0.89 \\
\hline Resim & 1 & 0.89 & Lunapark & 1 & 0.89 & & & \\
\hline
\end{tabular}

Tablo 4 incelendiğinde öğretmen adaylarının çoktan seçmeli maddelere ilişkin olarak toplam 112 adet geçerli metafor ürettikleri ve toplam 65 adet farklı metafor olduğu görülmektedir. En s1k tekrarlama sayısına sahip metaforlar; "Şans Oyunu (\%11.61), Piyango (\%7.14), Havuz (\%4.46), Kurtarıcı (\%4.46), Labirent (\%3.57) ve Dost (\%3.57)" olmuştur. Geri kalan metaforların büyük çoğunluğu olan 47 (\%41.96) metafor ise bir öğretmen aday1 tarafından ifade edilmiştir. $\mathrm{Bu}$ bağlamda öğretmen adayları tarafından çoktan seçmeli maddelere ilişkin çok sayıda farklı metafor kullanıldığı ortaya konulmuştur.

Öğretmen adaylarının belirtmiş oldukları metaforların nedenlerine ilişkin frekans ve yüzde değerleri ise Tablo 5'te verilmiştir.

Tablo 5. Öğretmen adaylarının çoktan seçmeli maddelere dersine ilişkin geliştirdikleri metaforların nedenleri, frekans ve yüzde değerleri

\begin{tabular}{lll}
\hline Nedenler & f & \% \\
\hline Şans faktörü vardır & 25 & 22.32 \\
Sinırları vardır & 15 & 13.39 \\
Tek bir doğru yanıtı vardır & 12 & 10.71 \\
Seçenekler arasından seçim yaptırır & 12 & 10.71 \\
Doğru yanıtı seçtirir & 11 & 9.82 \\
Ya kazandırır - ya kaybettirir & 10 & 8.93 \\
Hatırlatıcıdır & 5 & 4.46 \\
Kurtarıcıdır & 5 & 4.46 \\
Hızlı yanıt verilir & 4 & 3.57 \\
Ne çıkacağı belli değildir & 3 & 2.68 \\
Kafa karıştırıcıdır & 3 & 2.68 \\
Düşünceyi kısıtlar & 2 & 1.79 \\
Kolaydır & 2 & 1.79 \\
Yanlış tercihler doğruları götürür & 2 & 1.79 \\
Kalıcı değildir & 1 & 0.89 \\
\hline
\end{tabular}

Tablo 5'te yer alan metaforların nedenleri incelendiğinde öğretmen adaylarının \%22.32'si çoktan seçmeli maddelerde şans faktörü olduğunu, \%13.39'u sınırlarının olduğunu ve \%10.71'i ise tek bir doğru yanıtının olduğunu ve yine \%10.71'i seçenekler arasından seçim yaptırdı ğını belirtmiş̦tir. Metaforlara ilişkin olarak belirtilmiş nedenlerden diğerlerinin bir kısmı hatırlatıc1, kurtarıcı, kolay olması ve hızlı yanıt verilmesi gibi olumlu özellik olarak algılanan nedenlerdir. Diğerleri ise ya kazandırması - ya kaybettirmesi, ne çıkacağının belli olmaması, kafa karıştırıcı olması, düşünceyi kısıtlaması, kalıcı olmaması gibi olumsuz özellik olarak algilanan nedenlerdir.

Öğretmen adaylarının çoktan seçmeli maddelere yönelik sahip oldukları metaforların temalara atanma işlemi metaforlar ve nedenleri tekrar incelenerek gerçekleştirilmiştir. $\mathrm{Bu}$ bağlamda temalar; şans faktörünün olması, seçenekler arasından yanıt verilmesi, sınırlarının olması, tek bir doğru yanıtın olması, avantajlarının olması ve ya hep ya hiç olma durumu olarak belirlenmiştir. Hangi metaforların hangi temalar altında toplandığı Tablo 6' da sunulmuştur. 
Tablo 6. Öğretmen adaylarının geliştirdikleri metaforlar ve atandıkları temalar

\begin{tabular}{|c|c|c|c|}
\hline Tema & Metaforlar & $\mathbf{f}$ & $\begin{array}{l}\text { Metafor } \\
\text { Sayısı }\end{array}$ \\
\hline Şans faktörünün olmast & $\begin{array}{l}\text { Şans Oyunu (13), Piyango (8), Rus Ruleti (2), } \\
\text { Dart Tahtası (2), Kumar (2), Bowling (1), Kader } \\
\text { (1), Lunapark (1), Bilmece (1), Sürpriz Hediye } \\
\text { (1), Fal (1) }\end{array}$ & 33 & 11 \\
\hline $\begin{array}{l}\text { Seçenekler arasından } \\
\text { yanit verilmesi }\end{array}$ & $\begin{array}{l}\text { Hazır Gıda/Yemek (3), Açık Büfe (2), Hayat } \\
\text { (2), Televizyon (2), Kuruyemiş (2), Oy Pusulası } \\
\text { (1), Kavşak (1), Çikolata (1), Yapboz (1), Harita } \\
\text { (1), Armut (1), Renk (1), Navigasyon (1), Menü } \\
\text { (1), AVM (1) }\end{array}$ & 21 & 15 \\
\hline Sinırlarının olmast & $\begin{array}{l}\text { Havuz (5), Kapalı Kutu (2), Duvar (2) Kelepçe } \\
\text { (1), Bahçe (1), Sayı (1), Çerçeve (1), Dört Odalı } \\
\text { Ev (1), Lego (1), Resim (1), Gölet (1), Resmi } \\
\text { Kurum (1) }\end{array}$ & 18 & 12 \\
\hline $\begin{array}{l}\text { Tek bir doğru yanıtın } \\
\text { olmast }\end{array}$ & $\begin{array}{l}\text { Labirent (4), Bilim (3), Anahtar (2), Dört Duvar } \\
\text { (1), Ok ve Yay (1), Matematik (1), Demir (1), } \\
\text { Şimşek (1), Çelik Kasa (1), Puzzle (1), Nokta } \\
\text { Atış1 (1) }\end{array}$ & 17 & 11 \\
\hline Avantajlarının olmast & $\begin{array}{l}\text { Kurtarıcı (5), Dost (4), Hafıza Oyunu (1), Arı } \\
\text { (1), Metro (1), Uçak (1), Şeker (1), Leblebi (1) }\end{array}$ & 15 & 8 \\
\hline $\begin{array}{l}\text { Ya hep ya hiç olma } \\
\text { durumu }\end{array}$ & $\begin{array}{l}\text { Ameliyat (1), Batak Oyunu (1), Banka (1), } \\
\text { Bomba (1), Tek Yön (1), Metrobüs (1), Çember } \\
\text { (1) }\end{array}$ & 7 & 7 \\
\hline
\end{tabular}

Tablo 6'da altı farklı tema ve temalara atanmış metaforların yer aldığı görülmektedir. $\mathrm{Bu}$ temalar tek tek incelendiğinde en fazla tekrar eden metafor sayısına (33) sahip temanın 'Şans faktörünün olması' başlıklı tema olduğu ve bu tema altında 11 farklı metafor üretildiği görülmektedir. $\mathrm{Bu}$ temada öğretmen adaylarının çoktan seçmeli maddelerin olumsuz özelliklerinden bir tanesi olan "şans faktörünü" metaforlar aracılığıyla ortaya çıkarttıkları belirlenmiştir. Öğretmen adaylarının metafor ve nedenlerini nasıl ifade ettiklerine ilişkin örnekler aşağıda sunulmuştur.

'Çoktan seçmeli maddeler şans oyunu gibidir; çünkü şans faktörü hep vardır.'

'Çoktan seçmeli maddeler piyango gibidir; çünkü şans faktörü vardır.'

'Çoktan seçmeli maddeler Rus ruleti gibidir; çünkü bilmeyen biri için şanstır.'

Oluşturulmuş olan temalardan frekansı en yüksek olanlardan ikincisi "Seçenekler arasından yanıt verilmesi” temasıdır. Bu tema altında üretilmiş olan metaforlar ve nedenleri incelendiğinde, öğretmen adaylarının çoktan seçmeli maddelerde seçeneklerin hazır olarak sunulmuş olduğunu belirttikleri görülmüştür. $\mathrm{Bu}$ tema 21 frekansa sahip olup, 15 farklı metafora sahiptir. "Seçenekler arasından yanıt verilmesi" temasına ilişkin örnekler şöyledir;

'Çoktan seçmeli maddeler hazır gıda gibidir; çünkü seçenekler önüne hazır gelir.' al.

'Çoktan seçmeli maddeler açık büfe gibidir; çünkü her şık ayrı bir lezzet, seç, beğen ve

'Çoktan seçmeli maddeler televizyon gibidir; çünkü sadece sana verilenler arasından seçim yaparsın.'

"Sınırlarının olması" teması ise 18 frekansa ve 12 farklı metafora sahiptir. Bu tema altında üretilmiş olan metaforlar ve nedenleri incelendiğinde, çoktan seçmeli maddelerin 
aslında düşünceyi ve yanıt vermeyi kısıtladığı gibi ifadelerin yer aldığı görülmüştür. Bu temaya ilişkin örnekler aşağıda sunulmuştur.

'Çoktan seçmeli maddeler havuz gibidir; çünkü yüzeceğin alan ve derinlik bellidir.'

'Çoktan seçmeli maddeler kapalı kutu gibidir; çünkü sınırları kesindir.'

'Çoktan seçmeli maddeler kelepçe gibidir; çünkü düşünceyi kısitlar, belli kalıplarda bilgiyi önüne sunar.

"Tek bir doğru yanıtın olması" teması 17 frekansa ve 11 farklı metafora sahiptir. Bu tema altında çoktan seçmeli maddelerin özelliklerinden biri olan tek bir doğru yanıtın olması özelliği ifade edilmiştir. Bu temaya ilişkin örnekler aşağıda sunulmuştur.

'Çoktan seçmeli maddeler labirent gibidir; çünkü ne kadar dolaşırsan dolaş tek bir çıkış yolun vardir.' vardir.

'Çoktan seçmeli maddeler bilim gibidir; çünkü cevaplar arasında tek bir doğru yanıt

'Çoktan seçmeli maddeler anahtar gibidir; çünkü doğru cevabı bulduğunda kapı açılır.'

"Avantajlarının olması" teması 15 frekansa ve 8 farklı metafora sahiptir. Bu temaya ilişkin örnekler aşağıda verilmiştir.

'Çoktan seçmeli maddeler kurtarıcı gibidir; çünkü unuttuklarını hatırlatır.'

'Çoktan seçmeli maddeler dost gibidir; çünkü zor zamanında imdadına yetişir.'

'Çoktan seçmeli maddeler leblebi gibidir; çünkü kolay olur.'

"Ya hep ya hiç olma durumu" teması 7 frekansa ve metafora sahiptir. Çoktan seçmeli maddelerde yanıtlayıcı doğru yanıtı vermediği sürece sıfır puan alır. Dolayısıyla kısmi bilginin ve kısmi puanlamanın önemi yoktur. Bu özellik "ya hep ya hiç olma durumu” olarak temalaştırılmıştır ve bu temaya ilişkin örnekler aşağıda sunulmuştur.

'Çoktan seçmeli maddeler ameliyat gibidir; çünkü hata yapma şansin yoktur.'

'Çoktan seçmeli maddeler tek yön gibidir; çünkü yanlış yola girdiğinde dönüşü olmaz.'

'Çoktan seçmeli maddeler batak oyunu gibidir; çünkü ya batarsın ya da çıkarsın.'

\section{SONUÇ VE TARTIŞMA}

Bu araştırmada öğretmen adaylarının "açık uçlu" ve "çoktan seçmeli" maddelere ilişkin algıları metaforlar aracılığıyla belirlenmiştir. Daha önce açık uçlu ve çoktan seçmeli maddeler kapsamında yapılmış olan bir metafor çalışmasına rastlanmamıştır. Çalışma sonucunda açık uçlu maddelere ilişkin toplam 78, çoktan seçmeli maddelere ilişkin olarak da toplam 65 adet farklı ve geçerli metafor elde edilmiştir.

Açık uçlu maddeler kapsamında metafor ve nedenleri doğrultusunda açığa çıkan temalar; kapsamlı ve sonsuz oluşu, sınanana kendini ifade etme olanağı sunması, öznel ve yoruma açık oluşu, zor ve korkutucu olması ve zihinsel becerileri geliştirmesi olmak üzere toplam beş temadır. Temalardan en fazla frekansa sahip olan tema " kapsamının geniş olması" temasıdır. Bu temayı, "sınanana kendini ifade etme olanağı sunması", "öznel ve yoruma açık olması" temaları izlemektedir. Ortaya çıkan bu temalar açık uçlu maddelerle ilgili literatürle de desteklenmektedir ve araştırmacılar (Kastner ve Stangla, 2011; Messick, 1994; Rodriquez, 2002; Roid ve Haladyna, 1982) açık uçlu maddelerin; seçenekler arasından doğru yanıtı seçmek yerine sınananların kendi yanıtlarını yapılandırmalarını gerektirdiğini ifade etmektedir. $\mathrm{Bu}$ doğrultuda öğretmen adaylarının açı uçlu maddelere yönelik deneyimlerinin ve algılarının literatürle de örtüştüğü ifade edilebilir.

Öğretmen adaylarının açık uçlu maddelere ilişkin belirttikleri metaforlar kapsamında "zihinsel becerileri geliştirmesi" teması da yer almaktadır. Literatürde (Pollack, Rock ve 
Jenkins, 1992 ve Rodriquez, 2002) açık uçlu maddelerin kullanımıyla, sınanan bireydeki bilgiye ilişkin daha derin ölçme ve değerlendirme süreçlerinin gerçekleştirileceği belirtilmiştir. $\mathrm{Bu}$ doğrultuda açık uçlu maddelerin daha derin ölçmeler yaptığı için zihinsel becerileri geliştirdiği algılar aracılığıyla da ortaya konulmuştur.

Çoktan seçmeli maddeler kapsamında metafor ve nedenleri doğrultusunda açığa çıkan temalar; şans faktörünün olması, seçenekler arasından yanıt verilmesi, sınırlarının olması, tek bir doğru yanıtın olması, avantajlarının olması ve ya hep ya hiç olma durumu olarak belirlenmiştir. Çoktan seçmeli maddeler kapsamında oluşturulmuş olan temalardan en fazla frekansa sahip olan tema "şans faktörünün olması" temasıdır. Haladyna (1997) da çoktan seçmeli maddelerin sınırlılıklarını belirtirken doğru yanıtın bulunması noktasında ölçülen bilgiye sahip olunmaksızın test becerisiyle hareket etmeye yönlendirmesi ve şans başarısını ifade etmiştir. Çoktan seçmeli maddelerin en önemli dezavantajlarından biri şans faktörüne sahip olmasıdır. Ölçmek istenilen özelliğe sahip olmayan bir yanıtlayıcı dahi, şansla tam puan alabilmektedir. Ortaya çıkan metaforlar ve temalar incelendiğinde de bireylerin çoktan seçmeli maddelere yönelik zihinsel modellemelerinde şans başarısının oldukça yer edinmiş olduğu belirlenmiştir.

Metaforlar aracılığıyla ortaya çıkmış olan diğer temalar "seçenekler arasından yanıt verilmesi", "sınırlarının olması" ve "tek bir doğru yanıtın olması" temalarıdır. Bireyler seçeneklerin hazır olarak verildiğini, tek bir doğru yanıtın olduğunu ifade etmişlerdir. Aslında oluşturulmuş olan bu temalar çoktan seçmeli maddelerin sınırlarının olması temasıyla da ilişkilidir. Çoktan seçmeli maddelerin bireylerin algılarında düşünceyi kısıtlayan bir yönü vardir.

Ele alınmış olan bir diğer tema "ya hep ya hiç olma durumu" olarak belirtilmiştir. Literatürde ise bu durum öğrencilerin tam bilgiye sahip olmadığı sürece ya da ilgili alana ilişkin tam yetkinlik düzeyinde olmadığı sürece puan alamayacakları olarak belirtilmektedir (Wongwiwatthananukit, Popovich ve Bennett, 2000). Bu aynı zamanda kısmi bilginin dikkate alınmadığını da göstermektedir (Diedenhofen ve Musch, 2015). Yanıtlayıcıların bilgileri "tam bilgi" ve "bilginin yokluğu" olarak sinıflandırılmaktadır (Lau ve diğ., 2011).

Ortaya çıkan metaforlar ve temalar sonucunda açık uçlu maddelerin çoktan seçmeli maddelere göre bireylere kendini ifade etme olanağını sunduğu, öznel ve yoruma açık olduğu ve zihinsel becerileri geliştirdiği ifade edilebilir. Ancak çoktan seçmeli maddeler için tam tersi olarak sınırlarının olduğu metaforlar aracılığıyla ortaya konulmuştur. Özellikle şans faktörünün oluşu çoktan seçmeli maddelerin açık uçlu maddelere göre en önemli dezavantajlarından biridir. Literatür de ortaya çıkmış olan bu algıları desteklemektedir. Araştırmacılar (Kastner ve Stangla, 2011; Rodriquez, 2002) çoktan seçmeli maddelerin aksine açık uçlu maddelerin; sınananların kendi yanıtlarını yapılandırmalarını gerektirdiğini, daha derin ölçme ve değerlendirme süreçlerinin gerçekleştiğini ifade etmektedir. Yapılan araştırmalarda (Gültekin ve Demirtaşl1, 2012; Lukhele ve diğ., 1994 ve Sykes ve diğerleri, 2001) açık uçlu maddelerden oluşan testlerin çoktan seçmeli maddelerden oluşan testlere göre daha fazla bilgi verdiği sonucuna da ulaşılmış ve açık uçlu maddelerden oluşan testlerin diğer testlerden etkili olduğu ortaya konulmuştur.

$\mathrm{Bu}$ araştırmayla açık uçlu maddelerin çoktan seçmeli maddelere göre daha avantajlı olduğu metaforlar aracılığıyla ortaya konulmuştur. Ancak dikkat edilmesi gereken bir nokta, ölçmek istenilen özelliğe hangi madde türü daha çok hizmet ediyorsa o madde türünün kullanılması gerekliliğidir. Araştırmacılar da (Kastner ve Stangla, 2011; Martinez, 1999; Popham, 2008; Rodriquez, 2002; Roid ve Haladyna, 1982) hiçbir madde türünün yalnız başına tüm eğitim amaçlarına uygun olmadığını belirterek, farklı madde formatlarının farklı 
boyutlarda (bilişsel özellikler, madde, test karakteristiği ve ekonomik koşullar) daha güçlü olduğunu ileri sürmüştür.

Her iki madde türüne yönelik metaforlar ve nedenleri incelendiğinde olumlu metaforların yanı sıra olumsuz metaforların da olduğu dikkat çekmektedir. Açık uçlu maddelerin korkutucu, güvenilir olmayan ve uğraştırıcı olarak; çoktan seçmeli maddelerin ise kafa karıştırıcı, düşünce kısıtlayıcı olarak algılanması bu iki madde türüne ilişkin bilgilerin yeterli olmadığına ve her iki madde türünün de doğru kullanılmadığına ilişkin ipucu vermektedir. Madde türleri uygun biçimde yazıldığı takdirde metaforlarla da ifade edilen dezavantajların azaltılabileceği belirtilebilir. Bu noktada da Ölçme ve Değerlendirme derslerini yürüten öğretim elemanlarının, nitelikli madde yazımı ve amaca en iyi hizmet eden maddelerin kullanımına vurgu yapmaları önerilmektedir. Bununla birlikte, öğretmen adaylarının belirttiği metaforlar ve onlardan oluşan temalar doğrultusunda, geniş ölçekli test uygulamalarında, çoktan seçmeli maddelerle birlikte, açık uçlu maddelere yer verilmesi de önerilmektedir.

\section{KAYNAKÇA}

Arıkan, E.E. ve Ünal, H. (2014). Üstün ve normal yetenekli öğrencilerin problem kurmaya yönelik metaforik algıları. 9. Uluslararası Balkan Ĕ̈itim ve Bilim Kongresi, Trakya Üniversitesi, Edirne.

Arslan, M. M. ve Bayrakçı, M. (2006). Metaforik düşünme ve öğrenme yaklaşımının eğitimöğretim açısından incelenmesi. Milli Ĕgitim, 171, 100-108.

Aydın, İ. S. ve Pehlivan, A. (2010). Türkçe öğretmeni adaylarının "öğretmen” ve "öğrenci” kavramlarına ilişkin kullandıkları metaforlar. Turkish Studies, 5(3), 818-842.

Aydoğdu, E. (2008). İlköğretim okullarındaki öğrenci ve öğretmenlerin sahip oldukları okul algıları ile ideal okul algılarının metaforlar yardımıyla analizi (Yayınlanmamış yüksek lisans tezi). Osmangazi Üniversitesi, Eskişehir.

Baş, T., Akturan, U., Ataçkarapınar M., Atak, İ., Bağcı, F., Çamır, M. (2008). Nitel araştırma yöntemleri: NVIVO 7.0 ile nitel veri analizi. Seçkin Yayıncılık, Ankara.

Bozdemir, H. and Uluman, M. (2012). Primary school teacher freshmen'metaphoric perceptions in relation to university concept. Procedia-Social and Behavioral Sciences, 46, 1032-1036.

Bullough, Jr. R. Y. (1991). Exploring personal teaching metaphors in preservice teacher education. Journal of Teacher Education, 42(1),43-51.

Bullough, Jr. R. Y., \& Stokes, D.K. (1994). Analyzing personal teaching metaphors in preservice teacher education as a means for encouraging professional development. American Educational Research Journal, 31(1),197-224.

DeCarlo, L.T., Kim, Y.K. \& Johnson, M.S. (2011). A hierarchical rater model for constructed responses, with a signal detection rater model. Journal of Educational Measurement, 48(3), 333-356.

Demir, G. Y. (2005). Çevirenin önsözü. G. Lakoff \& M. Johnson (Yazarlar) Metaforlar: Hayat, anlam ve dil. İstanbul: Paradigma Yayıncilık.

Diedenhofen, B. and Musch, J. (2015). Empirical option weights improve the validity of a multiple-choice knowledge test. European Journal of Psychological Assessment.

Döş, İ. (2010). Aday öğretmenlerin müfettişlik kavramına ilişkin metafor algıları. Gaziantep Üniversitesi Sosyal Bilimler Dergisi, 9(3), 607-629.

Duman, G. ve Çetin, M. (2014) Çok kültürlü eğitim kavramına ilişkin öğretmen adaylarının metaforik algıları. 9.Uluslararası Balkan Eğitim ve Bilim Kongresi, Trakya Üniversitesi, Edirne.

Ekiz, D. ve Koçyiğit, Z. (2013). Sınıf öğretmenlerinin “öğretmen” kavramına ilişkin metaforlarının tespit edilmesi, Kastamonu Ĕ̈itim Dergisi, 21(3), 439-458. 
Giorgi, A. and Giorgi, B. (2003). Qualitative Pschology. Sage Publication, London.

Goldstein, L. S. (2005). Becoming a teacher as a hero's journey: Using metaphor in preservice teacher education. Teacher Education Quarterly, 7-24.

Gök, B., Erdogan, O., Özen-Altinkaynak, S. ve Erdogan, T. (2012). Investigation of pre-service teachers' perceptions about concept of measurement and assessment through metaphor analysis. Procedia-Social and Behavioral Sciences, 46, 1997-2003.

Gross, M. A., \& Hogler, R. (2005). What the shadow knows: Exploring the hidden dimensions of the consumer metaphor in management education. Journal of Management Education, 29(1), 3-16.

Gültekin, S. and Çıkrıkçı Demirtaşlı, N. (2012). Comparing the test information obtained through multiple-choice, open-ended and mixed item tests based on item response theory. Elementary Education Online, 11(1), 251-263.

Günal, Y. (2014). Rehber öğretmen adaylarının ölçme ve değerlendirme dersine ilişkin metaforik algıları. 9. Uluslararası Balkan Eğitim ve Bilim Kongresi, Trakya Üniversitesi, Edirne.

Güvendir, M. A. ve Özkan, Y. Ö. (2016). Öğretmen adaylarının ölçme ve değerlendirme dersine yönelik algılarının metaforlar yoluyla belirlenmesi. Dumlupınar Üniversitesi Sosyal Bilimler Dergisi, (47), 91-105.

Haladyna, T. M. (1997). Writing Test Items To Evaluate Higher Order Thinking. Allyn \& Bacon, 160 Gould Street, Needham Heights, MA 02194-2310.

Johnson, E. (2005). Proposition 203: A critical metaphor analysis. Bilingual Research Journal, 29(1), 69-84.

Kastner, M. ve Stangla, B. (2011). Multiple choice and constructed response tests: Do test format and scoring matter? Procedia-Social and Behavioral Sciences, 12, 263-273.

Kortens, M. (1988). Metaphor in education. Awarded Research Masters Thesis. Victoria University of Wellington.

Kurz, T.B. (1999). A review of scoring algorithms for multiple-choice test items. EDRS Publications, Report No: ED 428076.

Lakoff, G. ve Johnson, M. (2005). Metaforlar: Hayat, anlam ve dil, çev. Demir, G. Y. İstanbul: Paradigma Yayıncilik.

Lau, P. N. K., Lau, S. H., Hong, K. S. and Usop, H. (2011). Guessing, partial knowledge, and misconceptions in multiple- choice tests. Educational Technology and Society, 14, 99 110.

Lukhele, R., Thissen, D., Wainer, H. (1994), On the relative value of multiple choice, contructed response, and examinee selected items on two achievement tests. Journal of Educational Measurement, 31, 231-250.

Mahlios, M. and Maxson, M. (1998). Metaphors as structures for elementary and secondary preservice Teachers ${ }^{\text {ee }}$ thinking. International Journal of Educational Research, 29, 277240.

Mariano, L.T. (2002). Information accumulation, model selection and rater behavior in constructed response student assessments (Doktora Tezi). Carnegie Mellon University, Pennsylvania.

Martinez, M.E. (1999). Cognition and the questions of test item format. Educational Psychologist, 34(4), 207-218.

Messick, S. (1994). The interplay of evidence and consequences in the validation of performance assessments. Educational Researcher, 23(2), 13-23.

Nalçacı, A. ve Bektaş, F. (2012). Öğretmen adaylarının okul kavramına ilişkin algıları. Ahi Evran Üniversitesi Kırşehir Ĕ̈itim Fakültesi Dergisi, 13 (1), 239-258.

Özdemir, M. (2012). Lise öğrencilerinin metaforik okul algılarının çeşitli değişkenler bakımından incelenmesi. Eğitim ve Bilim, 37(163), 96-109. 
Palmquist, R. A. (2001). Cognitive style and users' metaphors for the web: An exploratory study. Journal of Academic Librarianship, 27(1), 24-32.

Pektaş, M. ve Kıldan, A. O. (2009). Farklı branşlardaki öğretmen adaylarının "öğretmen" kavramı ile ilgili geliştirdikleri metaforların karşılaştırılması. Erzincan Eğitim Fakültesi Dergisi, 11(2), 271-287.

Pollack, J. M., Rock, D. A. and Jenkins, F. (1992). Advantages and disadvantages of constructed-response item formats in large-scale surveys. In Annual Meeting of the American Educational Research Association, San Francisco.

Popham, W.J. (2008). Classroom Assessment What Teachers Need To Know. USA: Pearson Education.

Rodriquez, M. C. (2002). Choosing An Item Format. Tindal, G. ve Haladyna, T.M. (Ed.). Large-Scale Assessment Programs For All Students (213-231). New Jersey: Lawrence Erlbaum Associates Publishers.

Roid, G.H. and Haladyna T.M. (1982). A Technology For Test-Item Writing. New York: Academic Pres.

Saban, A. (2004). Giriş düzeyindeki sınıf öğretmeni adaylarının “öğretmen” kavramına ilişkin ileri sürdükleri metaforlar. Türk Ĕgitim Bilimleri Dergisi, 2(2), 131-155.

Saban, A. (2008). Okula ilişkin metaforlar. Kuram ve Uygulamada Eğitim Yönetimi, 55(55), 459-496.

Saban, A. (2009). Öğretmen adaylarının öğrenci kavramına ilişkin sahip olduğu metaforlar. Türk Ĕ̈itim Bilimleri Dergisi, 7(2), 281-326.

Saban, A., Kocbeker, B. N. and Saban, A. (2007). Prospective teachers' conceptions of teaching and learning revealed through metaphor analysis. Learning and Instruction, 17(2), 123139.

Simpson, J. F. (2007) More than simply hanging out: The nature of participant observation and research relationship (Unpublished PhD Thesis). University of New Hampshire, USA.

Stofflett, R. (1996). Metaphor development by secondary teachers enrolled in graduate teacher education. Teaching and Teacher Education, 12(6), 577-589.

Sykes, R. C., Truskosky, D., White, H. (2001), Determining the representation of constructed response items in mixed-item-format exams. Paper presented at Annual Meeting of the National Council on Measurement in Education, Seattle

Taşgın, A. ve Köse, E. (2015). Sınıf öğretmeni adaylarının hedef ve değerlendirme kavramlarına ilişkin metaforları. Hacettepe Üniversitesi Ĕgitim Fakültesi Dergisi, 30 (3), 116-130.

Tatar, N. ve Murat, S. (2011). Öğretmen adaylarının "değerlendirmeye" yönelik algıları. Uluslararası Ĕgitim Araştırmaları Dergisi, 2(4), 70-88.

Tavşancıl, E. ve Aslan, E. (2001). İçerik Analizi ve Uygulama Örnekleri. Epsilon Yayıncılık, İstanbul.

Töremen, F. ve Döş, İ. (2009). İlköğretim öğretmenlerinin müfettişlik kavramına ilişkin metaforik algıları. Kuram ve Uygulamada Eğitim Bilimleri, 9, 1973-2012.

Wongwiwatthananukit, S., Popovich, N. G. and Bennett, D. E. (2000). Assessing pharmacy student knowledge on multiple-choice examinations using partial-credit scoring of combined-response multiple-choice items. American Journal of Pharmaceutical Education, 64(1), 1.

Yalçın, M. ve Erginer, A. (2012). İlköğretim okullarında okul müdürüne ilişkin metaforik algılar. Öğretmen Ĕ̈itimi ve Ĕ̈itimcileri Dergisi, 1(2), 229-256.

Yıldırım, A. ve Şimşek, H. (2008). Sosyal bilimlerde nitel araştırma yöntemleri. Seçkin Yayınc1l1k, Ankara. 